\title{
Refugee Protection as Human Rights Protection: International Principles and Practice in India
}

\author{
Brian Gorlick and Sumbul Rizvi Khan
}

\begin{abstract}
This article focuses on the relationship between international human rights standards and refugee protection. The foundational status of the Universal Declaration of Human Rights and other human rights treaties are surveyed in light of India's international legal obligations. The authors argue that international human rights law and practice have had a significant impact on the protection activities of the Office of the United Nations High Commissioner for Refugees (UNHCR) both in countries of asylum, countries of origin and in relation to the United Nations and other human rights actors. In this context, courts and national human rights institutions are important players in safeguarding the rights of refugees. As none of the countries of South Asia is party to the international refugee instruments nor have any of them adopted a national refugee law or procedure, the activities of the Indian National Human Rights Commission stand out as a positive example of national institution expanding the legal protection of refugees in the region.
\end{abstract}

\section{Précis}

Cet article porte sur la relation entre critères internationaux en matière de droits humains et protection des réfugiés. Les statuts fondateurs de la Déclaration Universelle des droits de l'Homme et d'autres traités sur les droits humains sont analysés d̀ la lumière des obligations juridiques

Brian Gorlick, MA,LL.B., LL.M., is Legal Officer, UNHCR Delhi Office, New Delhi, India.

Sumbul Rizvi Khan, LL.B., is Associate Legal Officer, UNHCR Delhi Office, New Delhi, India.

The views expressed are those of the authors and not necessarily shared by the United Nations or UNHCR. internationales de l'Inde. Les auteurs développent une argumentation selon laquelle les lois et pratiques internationales en matière de droits humains ont un impact significatif sur les activités de protection assurées par l'Office $d u$ Haut Commissariat des Nations Unies aux réfugiés, autant dans les pays asiles, que dans les pays d'origine, et ce dans toute interaction entre les Nations Unies et les autres intervenants en matière de droits humains. Dans un tel contexte, les tribunaux et les institutions nationales traitant des droits humains sont des acteurs cruciaux en ce qui concerne la protection des droits des réfugiés. Comme aucun des pays d'Asie $d u$ Sud n'est engagé dans les grands mécanismes internationaux en matière de droit des réfugiés, et comme aucun d'entre eux n'a adopté de loi ou procédure nationale en matière de droit des réfugiés, les activités de la Commission Nationale Indienne des droits de l'Homme s'avèrent représenter un exemple positif d'institution nationale assurant le progrès de la protection légale des réfugiés dans cette région $d u$ monde.

\section{International Human Rights as a System of International Law}

Human rights are freedoms which are granted equally to all persons without distinction. In a sense, human rights can be considered universally recognized standards of behaviour. The violation of these standards by states, or other agents, may give rise to situations which lead to the creation of refugees. Refugees, by definition, are victims of human rights violations. ${ }^{1}$

Viewing the refugee problem in the context of human rights is clearly relevant. In fact the origin of the international system of refugee protection, as codified in international refugee law, grew out of concern for the plight of refugees fleeing the troubles of post- war Europe. Regrettably, protecting and assisting victims of human rights violations which result in forced displacement is as relevant today as it was some fifty years ago. However, refugees are not simply victims of human rights violations as they represent a distinct group of individuals who are without the protection of a national state. The international system of refugee law was adopted in order to replace the protection which is normally provided by and is the responsibility of national governments for their citizens.

The idea of developing a system of law which protects the human rights of individuals is also nothing new. Many states have been established on the basis that individuals have certain inherent rights which must be respected by the state. The idea of establishing a system of international human rights law is a more recent development which has been catalyzed through the United Nations. The 1945 UN Charter proclaims in its Preamble that "promoting and encouraging respect for human rights and for fundamental freedoms for all without distinction as to race, sex, language or religion" is a primary purpose of the United Nations. Member states of the UN pled ge themselves to take action in cooperation with the United Nations to achieve this purpose.

Apart from the UN Charter, the Universal Declaration of Human Rights of 1948 , and the Convention relating to the Status of Refugees of $1951,{ }^{2}$ a number of other international human rights standards and instruments have been developed and adopted by member states of the United Nations. These include the International Covenant on Civil and Political Rights (1966), the International Covenant on Economic, Social and Cultural Rights (1966)-collectively known as the International Bill of 
Rights-the Convention on the Prevention and Punishment of the Crime of Genocide (1948), the Convention relating to the Status of Stateless Persons (1954), and the Convention on the Elimination of Racial Discrimination (1965), and the Convention on the Elimination of Discrimination against Women (1979). More recently, the Convention against Torture and Other Cruel, Inhuman or Degrading Treatment or Punishment (1984), and the Convention on the Rights of the Child (1989) have been adopted at the international level.

In addition to the central foundationalstatus of the Universal Declaration of Human Rights, more than 189 states have ratified or adhered to at least one (or in the majority of cases more) of these international human rights treaties, thus establishing binding legal obligations of a continuing nature. Several South Asian states are party to the major human rights conventions in addition to the 1949 Geneva Conventions and their 1977 Additional Protocols governing the laws of war.

Among the international human rights treaties, India is party to the two international Covenants as well as the International Convention on the Elimination of All Forms of Racial Discrimination, the Convention on the Rights of the Child, and the Convention on the Elimination of All Forms of Discrimination Against Women. India has also ratified the Convention on the Political Rights of Women, the Convention on the Suppression and Punishment of the Crime of Apartheid, the Convention on the Non-Applicability of Statutory Limitations to War Crimes and Crimes against Humanity, and the Convention on the Prevention and Punishment of the Crime of Genocide. Most recently, India acceded to the 1984 Convention Against Torture. ${ }^{3}$

\section{Using "Human Rights" to Enhance the Protection of Refugees}

In the international system of human rights protection, the grant of asylum by a state to persons entitled to invoke Article 14 of the Universal Declaration of Human Rights cannot be regarded as an unfriendly act by another state. Simi- larly, and particularly in the post-Cold War context, it is widely acknowledged that international attention to human rights violations is not an interference in a country's domestic affairs but is rather part of routine international diplomacy. Although some states will go to great lengths to avoid scrutiny or criticism before international human rights bodies, the international community has identified a need to strengthen and improve application and enforceability of the international system of human rights protection. This has been realized through, for example, the UN-sponsored human rights missions in Cambodia, El Salvador, Guatemala, Haiti, the former Yugoslavia and Rwanda; the establishment of international criminal tribunals for the former $\mathrm{Yu}$ goslavia and Rwanda; and technical cooperation in the field of human rights with governments and other actors. Of course the degree varies, ranging from assistance and advice, to monitoring and reporting and direct protection.

In its own policies and programs, UNHCR has incorporated a number of human rights principles. Its protection activities in countries of asylum and countries of origin include working with states in the areas of legal rehabilitation, institution building, law reform and enforcement of the rule of law and providing humanitarian assistance to internally displaced persons. Increased cooperation with international and regional human rights mechanisms are also new areas of involvement for UNHCR. These activities add to an already overburdened agenda. Some states have expressed concern that UNHCR should not undertake tasks which go beyond its formal mandate. This concern is well taken as these more recent activities are placing considerable strain on UNHCR's limited resources. In this context the question of whether UNHCR has the capacity and capability to do these tasks must be addressed. Despite these apprehensions, in this era of downsizing and reform of the UN system it seems unlikely that
UNHCR will be permitted to continue its activities along traditional lines. Furthermore, "in country" protection activities are becoming increasingly formalized as part of UNHCR's evolving protection mandate. ${ }^{4}$

In efforts to prevent refugee flows the UN and others, notably NGOs, are providing technical assistance to states within a general human rights framework. This includes the promotion of human rights standards through the training of judges, lawyers, and human rights activists; giving substance to educational rights by funding the construction of new schools in war-torn countries; and promoting economic rights through communitybased projects focused on providing assistance to returning refugees. Promoting enactment and enforceability of domestic refugee and human rights laws, promotion of national human rights institutions, and training of government authorities, are other prevention-oriented activities in which the UN, governments, and NGOs are increasingly engaged.

As part of the development of human rights principles through UN Conventions, a number of international treaty bodies have been established to investigate violations, enforce standards, and assist states in implementing their treaty obligations. These bodies have the authority to examine periodic state party reports regarding implementation of the treaty provisions. With the agreement of states, some treaty bodies have the competence to investigate and decide upon individual and inter-state complaints and undertake field missions in order to monitor implementation measures. During examination of state party reports the committees may prepare formal conclusions and observations on the performance of states in complying with international human rights law. They may also formulate specific recommendations to governments. In recent years, some of these committees such as the Human Rights Committee, the Committee on the Rights of the Child, and the Committee Against Torture, have regularly raised 
issues about the treatment of refugees by state parties to the respective Conventions. ${ }^{5}$

The UN human rights machinery has paid increasing attention to the plight of refugees. This raises awareness of refugee protection issues through promotinglegal standards for refugees and internally displaced persons in addition to sharing information concerning incidents of violations of refugees' rights. Human rights NGOs and UNHCR have played key roles in educating members of the international and domestic human rights communities on the linkages between safeguarding human rights and refugee protection. These initiatives have firmly entrenched human rights issues in relation to the refugee problem. ${ }^{6}$

\section{National Human Rights Institutions and Refugee Protection: The Indian Experience}

On a regionalbasis a number of human rights treaties have been adopted. These include the European Convention for the Protection of Human Rights and Fundamental Freedoms (1950), the American Convention on Human Rights (1969), and the African Charter on $\mathrm{Hu}$ man and Peoples' Rights (1981). In South Asia, despite efforts in this direction, no regional human rights framework has yet been established. However, several Asian states have enacted or have expressed their commitment to enacting national human rights legislation. ${ }^{7}$

In the absence of a formal legal framework governing the treatment of refugees, several South Asian countries have chosen to manage influxes of refugees through administrative decisions rather than through specific legislative enactments. This has advantages in that it allows for flexibility in the granting of asylum. India, for example, generously accepts large groups of refugees who are fleeing not just for reasons relating to persecution, but also due to generalized violence as is the case of Sri Lankan Tamils. However, this does not hold good for all groups as certain refugees like Afghans, Iranians, Iraqis, Somalis, Suda- nese, and Myanmarese are not recognized by the Indian Government. For which reason UNHCR has had to intervene through determining and granting refugee status under its mandate.

This differential treatment of refugees is a fundamental problem. It negates the provision of legal rights and assistance which would normally be granted by an asylum country. Moreover, it is not clear what legal status or rights accrue to a person as a result of registration by the government of India as a refugee, nor the relationship between "refugee" status granted by the government and corresponding national laws governing the entry and stay of foreigners. ${ }^{8}$

Although the host of international human rights instruments which have been ratified by India and other South Asian countries may significantly strengthen the international regime of human rights protection in the region, ${ }^{9}$ it remains a curiosity that none of the South Asian countries have acceded to the international refugee instruments. ${ }^{10}$ Nor have any of them enacted a domestic legal framework in the form of a refugee or asylum law or determination procedure. ${ }^{11}$ In the absence of a domestic legal framework and procedure, national human rights institutions and the courts can play an important role.

The 1993 Protection of Human Rights $A c t^{12}$ established the Indian National Human Rights Commission (NHRC or Commission). Under the Act the NHRC has a wide range of powers and functions. First and foremost, it may inquire suo moto or on the basis of a petition the violation of human rights of any person. ${ }^{13}$ Under its authority the NHRC can intervene in any human rights proceeding before any Court, or visit any jail or other institution under control of the state government to investigate illegal detentions or conditions of legal detentions. ${ }^{14}$ The NHRC is authorized to review legal provisions and factors inhibiting the enjoyment of human rights in India and make recommendations to remedy any violation. It is also empowered to summon and examine witnesses, requisition and discover documents including public records, consider affidavit evidence and undertake field investigations. ${ }^{15}$

The NHRC may study treaties and international instruments on human rights and make recommendations on their effective implementation along with promoting research and performing functions necessary for the promotion of human rights. In respect of this particular function the Commission reportedly played an active role in encouraging the Indian government to accede to the UN Convention against Torture.

The NHRC comprises a chairperson who has been a Chief Justice of the Supreme Court of India, a member who has been a Judge of the Supreme Court, a member who has been a Chief Justice of a High Court, and two other members with experience in the field of human rights. ${ }^{16}$ Under the $A c t, \mathrm{Hu}$ man Rights Commissions may also be established at the state level. The organizational set-up of the state Commissions are quite similar to that of the National Commission with the Chairperson being a former Chief Justice of the High Court. ${ }^{17}$ At the state-level the Act provides for the establishment of Human Rights Courts for the purpose of providing speedy trial of offences arising out of violations of human rights. To assist the Court, the state government is also permitted to appoint an experienced Public Prosecutor or advocate as Special Public Prosecutor who would be responsible for conducting cases. ${ }^{18}$

Till date, the NHRC has been considerably active in the field of protection of human rights of refugees. Specific interventions made by the Commission have resulted in wideranging consequences relating to the protection of Chakma refugees who have sought refuge in the Northeastern states of India, particularly the States of Arunachal Pradesh and Tripura. It has also effectively intervened and continues to do so in cases of illegal detention of Sri Lankan Tamil refugees in the State of Tamil Nadu. 
Details of these interventions are discussed below.

In 1994, an Indian NGO, the Peoples' Union for Civil Liberties (PUCL), spearheading the complaints made by the Chakmas and Hajong refugees, approached the NHRC for redress of their grievances which related to the non-grant of citizenship and attempts at their forcible expulsion from India. Intimidatory tactics employed against the refugees included acts of looting, threats, and physical violence targeting Chakma and Hajong refugees in Arunachal Pradesh. The Commission took steps to verify the authenticity of the grievances by writing to the central and concerned state government, and upon not obtaining a favourable response it sent an inspection team comprising senior officials of the NHRC and the PUCL. The matter was pursued further, and due to lack of cooperation on the part of the State of Arunachal Pradesh the Commission took the initiative and filed a writ petition before the Supreme Court of India.

The Supreme Court granted interim orders for non-expulsion of the refugees till the final disposal of the case. Thereafter, in January 1996, the Supreme Court issued final orders which inter alia recognized that there exists a clear and present danger to the lives and personal liberty of the refugees. The Court further upheld that the protection of Article 21 of the Indian Constitution which ensures the right to life and liberty, is applicable to all irrespective of whether they are Indian citizens. The Supreme Court thus ordered that the refugees cannot be deprived of their life or personal liberty except in accordance with the procedure established by law. Specific directions were issued to the state government to the effect that

... the State shall ensure that the life and personal liberty of each and every Chakma residing within the State shall be protected and any attempt to forcibly evict or drive them out of the State ... shall be repelled, if necessary by requisitioning paramilitary or police force ...
Orders were also passed for ensuring that applications for Indian citizenship made by the Chakma refugees would be duly recorded and forwarded to the central government for consideration. The decision of the Indian Supreme Court is hailed as a landmark judgment in respect of safeguarding fundamental constitutional rights of foreigners, in this case a group of refugees. ${ }^{19}$ Although the judgment is rather limited in its discussion of the scope of the "rights" applicable to refugees in India, it is a most helpful pronouncement which has since been referred to repeatedly in respective High and Lower-level courts in India that "refugees," however defined, should be granted certain legal protection in India. More broadly, the decision is a successful example of the National Human Rights Commission following-up a refugee case as intervenor to the Supreme Court. It this respect it creates a favourable precedent.

Another case taken up by the NHRC concerned a number of Jumma refugees in the State of Tripura. In mid1996 the Commission sent a team to the Jumma refugee camps to investigate allegations concerning the poor camp conditions which, as one NGO pointed out, had the effect of pressuring the refugees to repatriate. After conducting its investigation the team reported on the woefully inadequate accommodation, health and food facilities in the refugee camps. The Commission took up the matter with the state and central governments and is actively involved in enhancing the quality of life in the Jumma refugee camps. As a result of these interventions camp conditions have improved. However, neither UNHCR nor ICRC have been provided a role in the ongoing repatriation exercise to Bangladesh.

The NHRC has also successfully intervened in a number of cases of Sri Lankan Tamil refugees who had been detained in so-called "special camps" in Tamil Nadu on the suspicion of being LTTE militants. A number of these refugees had been issued refugee permits by the state government recogniz- ing their refugee status and thereby authorizing their stay in India. Despite grant of the permits, many refugees were detained for illegal entry and unauthorized stay in India under the Foreigners Act. The Commission took up these cases with the state government and obtained the release of many refugees.

The above examples demonstrate that NHRC can play a powerful role in protecting the rights of refugees. In considering the Indian experience it should be noted that the resources of the Commission simply cannot keep pace with the number of complaints it receives, as it is estimated that the NHRC receives over 2,000 communications monthly and has a backlog in excess of 25,000 cases. In such circumstances the delivery of justice will never be satisfactory. Nevertheless, the work of the Indian National Human Rights Commission stands out as a positive example of an accessible and functioning national human rights institution.

The ability and willingness of the Commission to take up the cause of refugees in the future will depend on many factors. These include the quality and presentation of complaints which come to its attention, as well as the crucial part played by advocates and NGOs in pursing such matters before the NHRC. In this regard the work of the national Commission should have a positive impact on the emerging activities of the state-based human rights commissions. As an institution which enjoys an independence of process and procedure, and as a result of the status and expertise of its members, there are high expectations that the NHRC will continue to play an important role in safeguarding and expanding the legal protection of refugees in India.

\section{Notes}

1. A key element of the refugee definition as found in the 1951 Refugee Convention is fleeing one's country of origin "owing to a well-founded fear of persecution." Persecution is not defined in international refugee or human rights law. However, one commentator has offered the follow- 
ing description: "[P]ersecution may be defined as the sustained or systematic violation of basic human rights demonstrative of a failure of state protection. A well-founded fear of persecution exists when one reasonably anticipates that the failure to leave the country may result in a form of serious harm which Government cannot or will not prevent ...", James Hathaway, "Fear of Persecution and the Law of Human Rights," Bulletin of Human Rights 91/1, UN, New York (1992): 99.

2. There are currently 134 state parties to the 1951 Convention and/or the 1967 Protocol relating to the Status of Refugees. Article 1(A) of the 1951 Convention defines a refugee as any person who "owing to a well-founded fear of being persecuted for reasons of race, religion, nationality, membership of a particular social group or political opinion, is outside the country of his or her nationality and is unable or, owing to such fear, is unwilling to avail him or herself of the protection of that country; or who, not having a nationality and being outside the country of his or her habitual residence as a result of such events, is unable or owing to such fear, is unwilling to return to it ..."

3. In a statement issued by the Indian Ministry of External Affairs it was noted that India's accession to the Convention against Torture is part of "India's determination to uphold the greatest values of Indian civilization and our policy to work with other members of the international community to promote and protect human rights."

In the refugee context, ratification of the Convention against Torture is extremely important as Article 3(1) provides that "[n]o State Party shall expel, return ("refouler") or extradite $a$ person to another State where there are substantial grounds for believing that he or she would be in danger of being subjected to torture." Article 3(2) further provides that "[f]or the purpose of determining whether there are such grounds, the competent authorities shall take into account all relevant considerations including, where applicable, the existence in the State concerned of a consistent pattern of gross, flagrant or mass violations of human rights" (emphasis added).

For a description of the mandate and activities of the Committee established under the Convention against Torture see Brian Gorlick, "Refugee Protection and the Committee Against Torture," IJRL 7, no. 3, July 1995.

4. For a description of the changing nature of UNHCR's mandate see Guy S. Good-
win-Gill, The Refugee in International Law (2nd ed.), in particular Chapter 1, (Oxford: Clarendon Press, 1996); also see William Clarence, "Field Strategy for Human Rights Protection," IJRL 9, no. 2 (April 1996): 232-33.

5. For example, the third periodic report of India was examined by the UN Human Rights Committee during its sixtieth session held at Geneva. In its Concluding Observations under the heading "Subjects of Concern and Committee's Recommendations," the Committee remarked as follows: "The Committee, noting that international treaties are not self-executing in India, recommends that steps be taken to incorporate fully the provisions of the Covenant into domestic law, so that individuals may invoke them directly before the courts. The Committee also recommends that consideration be given by the authorities to ratifying the Optional Protocol to [International Covenant on Civil and Political Rights], enabling the Committee to receive individual communications relating to India." (Para. 13). Concerning refugees, the Human Rights Committee further stated: "The Committee expresses concern at reports of forcible repatriation of asylum seekers, including those from Myanmar (Chins), the Chittagong Hill Tracts and Chachmas (sic). It recommends that, in the process of repatriation of asylum seekers or refugees, due attention be paid to the provisions of the Covenant and other applicable international norms." (Para. 30). See UN Document CCPR/C/ 60/IND/3 of 30 July 1997.

6. A useful compilation of the various activities of the UN human rights mechanisms concerning refugees and issues of forced displacement is found in the UN Commission on Human Rights report "Human Rights, Mass Exoduses and Displaced Persons," UN Document E/ CN.4/1997/42 of 14 January 1997.

7. At the 2nd Asia-Pacific Regional Workshop held in New Delhi on 10-12 September 1997 the government delegates of Bangladesh and Nepal indicated they are in the process of establishing national human rights institutions through enacting legislation.

8. For a summary of the legal situation facing refugees in India see B. S. Chimni, "The Legal Condition of Refugees in India," Journal of Refugee Studies 7, no. 4, OUP, 1994. Also see Sumbul Rizvi Khan, "Response of the Indian Judicial System to the Refugee Problem," Bulletin on IHL $\&$ Refugee Law 2, no. 1, Indian Centre for Humanitarian Laws and Research, New Delhi, 1997.
9. As concerns the application of international human rights standards in domestic law the former Chief Justice of India, J. S. Verma, noted in his inaugural speech to the seminar on "Refugees in the SAARC Region" held in New Delhi in May 1997 that "[i]n the absence of national laws satisfying the need [to protect refugees\}, the provisions of the [1951 Refugee] Convention and its Protocol can be relied on when there is no conflict with any provision in the municipal laws. This is a canon of construction, recognized by the courts in enforcing the obligations of the state for the protection of the basic human rights of individuals. It is more so when the country is a signatory to the International Convention which implies its consent and obligation to be bound by the International Convention, even in the absence of expressly enacted municipal laws to that effect..." For a recent judicial application of this reasoning see the Indian Supreme Court judgment of Vishaka et al.v. Rajastan et al., Writ Petition (Criminal) Nos. 666-70 of 1992, unreported judgment of 13 August 1997.

It is also noteworthy that certain "rights" provisions of the Indian Constitution including Articles 14 (right to equality) and 21 (right to life and liberty) are available to non-citizens including refugees. See National Human Rights Commission v. State of Arunachal Pradesh et al., op. cit., and Khudiram Chakma v.. Union of India, (1994) Supp 1 SCC 614.

10. In a speech to the 48th Session of the UNHCR Executive Committee, then Indian Permanent Representative to the UN, Ms. Arundhati Ghose, explained India's reluctance to accede to the 1951 Refugee Convention as follows: "The 1951 Convention was adopted in the specific context of conditions in Europe during the period immediately after the second world war. International refugee law is currently in a state of flux and it is evident that many of the provisions of the Convention, particularly those which provide for individualized status determination and social security have little relevance to the circumstances of developing countries today who are mainly confronted with mass and mixed inflows. Moreover, the signing of the Convention is unlikely to improve in any practical manner the actual protection which has always been enjoyed and continues to be enjoyed by refugees in India. We therefore believe that the time has come for a fundamental reformulation of international refugee law to take into account present day realities ... it has be recognized that refugees and mass movements are first and foremost a 'developing coun- 
try" problem and that the biggest "donors" are in reality developing countries who put at risk their fragile environment, economy and society to provide refuge to millions. An international system which does not address their concerns adequately cannot be sustained in the long run ..."

11. Although no South Asian country has yet adopted a domestic refugee law or procedure a recent "Model Law on Refugees" was adopted at the 4th Regional Consultation on Refugees and Migratory Movements in South Asia held in Dhaka in November 1997. It is expected that this Model Law will provide a point of departure for continued debate and discussion on the form and content of a national refugee legislation which may be appropriate in the context of South Asia.

12. The Protection of Human Rights Act, No. 10 of 1994.
13. Ibid., Section 12.

14. Ibid.

15. Ibid., Sections 13 and 14.

16. Ibid., Section 4.

17. Ibid., Section 21.

18. Ibid., Sections 30 and 31.

19. National Human Rights Commission v. State of Arunachal Pradesh and another, (1996) 1 SCC 295.

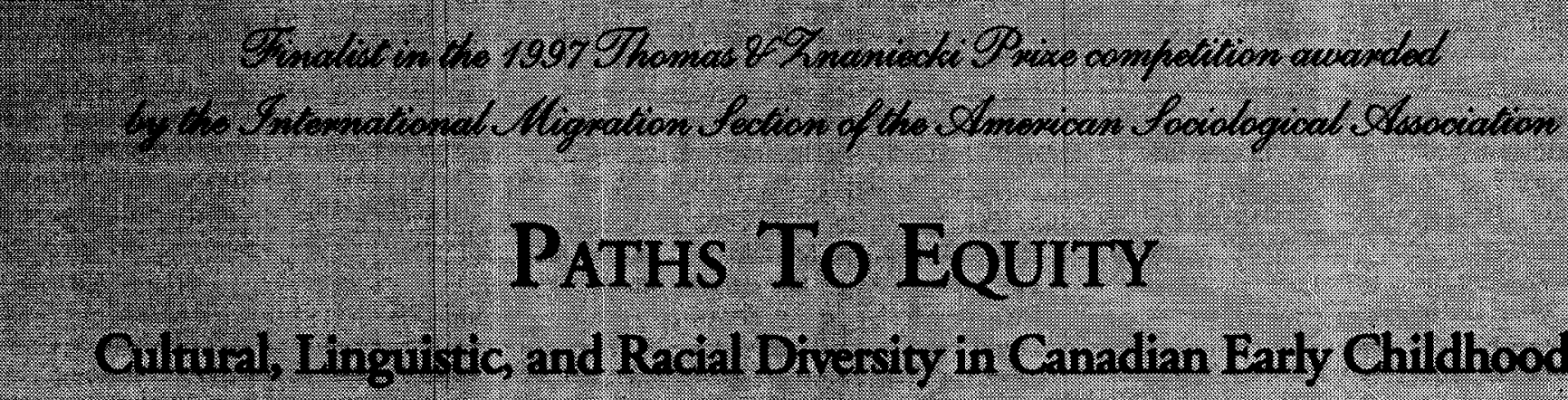

\section{Education}

\author{
By

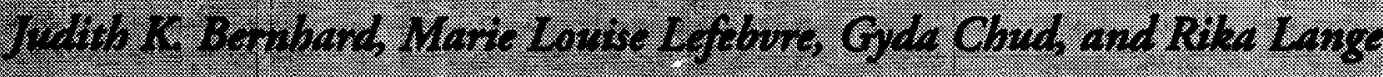

Toronto: York Lanes Pres; ISBN 1-55014-277-1, 112 pages, size 8.5×11; $\$ 18.95$

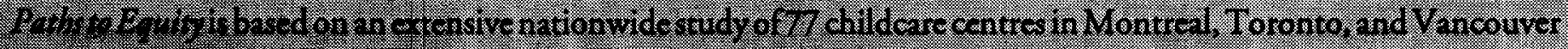

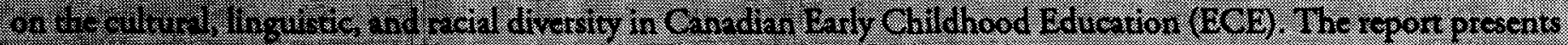
the rasullex this crudy on how the ECE system is responding to the increasing diversity of contemporary Canadian

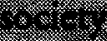

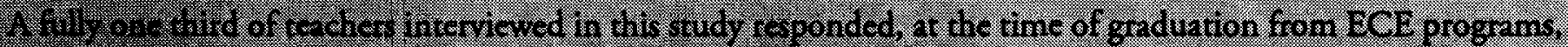
fid rat red thatiley were well prepared to work ffectively with childen and parents from diverse backgrounds. In this cround-brel lang study, the authors have addressed reachers' vieys on diversity in the education programs:

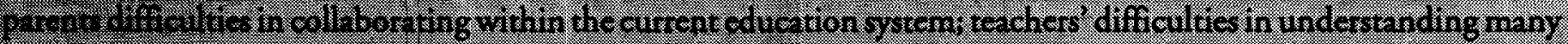
fethinget parenger desire of miny parents for better comminication with staff, preferably in their own languages, and for seove 1 formation abour their individual children, and chances for effective input; and the evidence of some

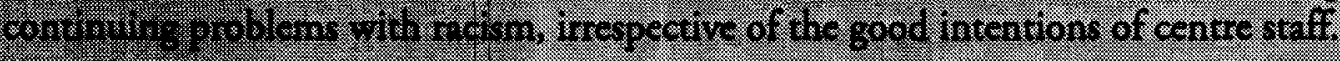

P.th th E, th will bo of interest to ECE feculty, policymakes, centre supervisors and staff and others incerested inthey indesion of diversity content in professional education programs.

$$
\text { 4unitublefrom: }
$$

Centro for Refuze- Stridies, York University

Surte 333, York Lanes, 4700 Koele Street

Toronto ON Canada M3j $1 \mathrm{P3}$

Fax:(416) 736-5837 : Email: refugeceyorku.ca 